\title{
Proanthocyanidins polymeric tannin from Stryphnodendron adstringens are active against Candida albicans biofilms
}

\author{
Raul Leal Faria Luiz , Taissa Vieira Machado Vila', João Carlos Palazzo de Mello², Celso Vataru Nakamura³, \\ Sonia Rozental ${ }^{1}$ and Kelly Ishida ${ }^{4^{*}}$
}

\begin{abstract}
Background: Biofilm formation is important in Candida albicans pathogenesis and constitutes a mechanism of antifungal resistance. Thus, we evaluated the effect of proanthocyanidins polymer-rich fractions from Stryphnodendron adstringens (fraction F2 and subfraction F2.4) against C. albicans biofilms.

Methods: Firstly, the antifungal activity of F2 and F2.4 against planktonic cells of Candida albicans (ATCC 10231) was determined using broth microdilution method. Anti-biofilm effect of F2 and F2.4 was evaluated during biofilm formation or on mature biofilm of C. albicans and compared with standard antifungals amphotericin B and fluconazole. Metabolic activity of sessile and dispersion cells from biofilms after antifungal treatments were measured using a tetrazolium reduction assay and the biofilm total biomass was quantified by crystal violet-based assay. Morphological alterations after treatments were observed using scanning electron microscopy.
\end{abstract}

Results: The anti-biofilm effect of F2 and F2.4 were comparable to standard antifungals (amphotericin B and fluconazole). F2 and F2.4 treatments reduced biofilm metabolic activity (in sessile and in dispersion cells) during biofilm formation, and in mature biofilms, unlike fluconazole, which only prevents the biofilm formation. Treatments with F2, F2.4 or fluconazole reduced biofilm biomass during biofilm formation, but not in mature biofilm. Amphotericin B presented higher inhibitory effect on biofilm formation and on mature biofilm of C. albicans. F2 and F2.4 treatments led to the appearance of dumbbell-shaped blastoconidia and of blastoconidia clusters in biofilms.

Conclusion: Proanthocyanidins polymer-rich fractions from S. adstringens successfully inhibited C. albicans planktonic growth and biofilm development, and they represent a potential new agent for the treatment of biofilm-associated candidiasis.

Keywords: Antifungal, Biofilm, Candida albicans, Proanthocyanidin, Stryphnodendron adstringens, Tannins

\section{Background}

Candida spp. are commensal yeasts that, in healthy individuals, colonize mainly mucosal surfaces of the oral cavity, and the gastrointestinal and urogenital tracts, without causing disease symptoms. However, these fungi may cause opportunistic infections in humans with certain physiological disorders, or in patients who have become immunocompromised or are undergoing therapy with

\footnotetext{
* Correspondence: ishidakelly@usp.br

${ }^{4}$ Laboratório de Quimioterapia Antifúngica, Departamento de Microbiologia, Instituto de Ciências Biomédicas, Universidade de São Paulo, Av. Prof. Lineu Prestes 1374, 05508-900 SP, Brazil

Full list of author information is available at the end of the article
}

broad-spectrum antibiotics. About $96 \%$ of all opportunistic mycoses are caused by Candida sp. [1], and C. albicans is still the major pathogenic species worldwide, causing $90 \%$ of vulvovaginal candidiasis [2] and 50 $70 \%$ of invasive candidiasis cases [3], with a mortality rate of $30-40 \%$ [3].

In Brazil, Stryphnodendron adstringens (Mart.) Coville (Leguminosae) is one of the most frequently used medicinal plants in the treatment of vaginal infections and wounds, and it is also used as astringent, anti-diarrhoeal, antimicrobial or hypoglycaemic agent [4]. The stem bark of $S$. adstringens is rich in tannins (10-37\%) [4], representing mainly flavan-3-ols and proanthocyanidins, such 
as prodelphinidins and prorobinetinidins [5-7]. Previous pharmacological studies have demonstrated that tannins extracted from $S$. adstringens stem bark have healing properties [8], analgesic and anti-inflammatory activity [9] and gastric anti-ulcerogenic effects [10]. Several studies have also demonstrated that tannins from S. adstringens have inhibitory activity against parasitic protists [11-13], viruses [14] and bacteria [9,15].

Previous reports from our group have demonstrated the antifungal activity of fractions derived from $S$. adstringens stem bark (fraction F2 and subfraction F2.4) against planktonic cells (in suspension) from vaginal isolates of Candida spp. [7], and against Cryptococcus neoformans [16]. Treatment with the proanthocyanidin polymeric tannins present in subfraction F2.4 (hexameric polymer with monomeric units of prodelphinidins, prorobinetinidins and gallic acid residues with molecular weight 2,114 $\mathrm{Da}$.) also altered some virulence factors of C. albicans as well as led to alterations in budding and on cell wall morphology [7]. In addition, toxicological studies using rodents have also reported low side effects after treatment with proantocyanidin polymerrich fraction (F2) $[17,18]$.

Biofilms are defined as heterogeneous microbial communities of cells adhering to an abiotic or biotic surface, while embedded in a polymeric extracellular matrix (produced by biofilm cells). In biofilms, microbial cells display altered phenotypes in comparison to those observed in planktonic cells of the same species and strain, mainly in their increased resistance to antifungal treatments $[19,20]$. C. albicans biofilms are resistant to a variety of clinical antifungal agents, including amphotericin B and fluconazole $[19,20]$, the major antifungal agents used for the treatment of both superficial and invasive candidiasis [21].

The development of new molecules with activity against $C$. albicans biofilms is paramount to add to the limited therapeutic options currently available for the effective treatment of Candida infections involving biofilm formation. Previously, we showed that S. adstringens fraction F2 and subfraction F2.4 are active against Candida albicans planktonic cells [7]. In this work, we extend these findings by demonstrating that fraction F2 and subfraction F2.4 from S. adstringens are also effective against $C$. albicans biofilms, and against dispersion biofilm cells, which are important for disease dissemination inside the host.

\section{Methods}

\section{Microorganism}

Antifungal effects were tested against Candida albicans ATCC 10231. This strain was maintained in Sabouraud dextrose agar (Becton, Dickinson and Company, Sparks, USA) at $4^{\circ} \mathrm{C}$ and subcultured twice in the same medium at $35^{\circ} \mathrm{C}$, for $24 \mathrm{~h}$ before each assay.

\section{Extraction}

Stryphnodendron adstringens stem bark was collected in São Jerônimo da Serra, Paraná, Brazil, in March 2010. A voucher specimen was deposited at the Herbarium of the Universidade Estadual de Maringá (HUEM \#14321), and it was identified by Prof. Dr. Cássia Mônica Sakuragui (Federal University of Rio de Janeiro). The stem bark was dried at room temperature and pulverized. Fraction F2 and subfraction F2.4 were prepared as described by Ishida and co-workers [7], and kept as lyophilized extracts at $-20^{\circ} \mathrm{C}$ in small aliquots. As previously reported, subfraction F2.4 consists of a hexameric tannin composed of monomeric units of prodelphinidins and prorobinetinidins, and gallic acid residues (molecular weight, 2,114 Da) [7]. The method of fractions preparation was validated by Costa et al. [22], and the subfraction 2.4 was identified by solid-state nuclear magnetic resonance (NMR) spectrometry using a Varian spectrometer (Mercury Plus 300 [7.02T]) operating at $75 \mathrm{MHz}$ for ${ }^{13} \mathrm{C}$ and 300 $\mathrm{MHz}$ for ${ }^{1} \mathrm{H}$. The identities of the polymeric tannin in subfraction F2.4 were confirmed using ${ }^{13} \mathrm{C}$ NMR, by comparison of the spectrum obtained here with results reported by Ishida et al. [7].

\section{Antifungal agents}

Two antifungal were used as references: fluconazole (FLC; Pfizer, São Paulo, Brazil), diluted in water $(2,000 \mu \mathrm{g} / \mathrm{mL})$ and amphotericin B (AMB; Sigma Chemical Co., USA), diluted in DMSO $(1,600 \mu \mathrm{g} / \mathrm{mL})$ and stored at $-20^{\circ} \mathrm{C}$.

\section{Antifungal susceptibility tests on planktonic cells}

The antifungal susceptibility of C. albicans ATCC 10231 planktonic cells was assessed by broth microdilution assay as described in Document M27-A3 [23]. The concentrations tested were: $0.48-250 \mu \mathrm{g} / \mathrm{mL}$, for fraction F2 or subfraction F2.4; $0.03-16 \mu \mathrm{g} / \mathrm{mL}$ AMB; and 0.125 $64 \mu \mathrm{g} / \mathrm{mL}$ FLC. The minimum inhibitory concentration (MIC) value is defined as the lowest concentration that inhibit $50 \%$ of fungal growth $\left(\mathrm{IC}_{50}\right.$, for azoles) or $90 \%$ of fungal growth ( $\mathrm{IC}_{90}$, for polyenes) determined by visual inspection or spectrophotometric reading at $492 \mathrm{~nm}$ in a microtitre plate reader (SpectraMAX 340 Tunable Microplate Reader, Molecular Devices Ltd, USA) [23]. Here, we also considered the $\mathrm{IC}_{50}$ value to be the MIC for the fraction F2 and subfraction F2.4 from $S$. adstringens.

The MFC is defined as the lowest concentration of a given compound that fails to produce fungal growth, and was determined by transferring an aliquot of fungal samples treated with concentrations higher than the MIC into fresh Sabouraud dextrose agar plates, which were then incubated at $35^{\circ} \mathrm{C}$ for $48 \mathrm{~h}$. Fungicidal effects were considered significant when the MFC value was $\leq 4 \times$ $\mathrm{MIC}$ value. Above this value, the antifungal effect was considered fungistatic [24]. 


\section{Treatment of biofilms with antifungal agents}

To evaluate the effect of antifungals on biofilm formation, we used a protocol modified from previously described assays for C. albicans biofilm formation and antifungal treatment $[25,26]$. Aliquots of $100 \mu \mathrm{L}$ of $C$. albicans ATCC 10231 yeast suspensions $\left(1 \times 10^{7} \mathrm{CFU} / \mathrm{mL}\right.$, in RPMI 1640 medium buffered with 0.16 MOPS and supplemented with $2 \%$ glucose) were transferred into each well of polystyrene, flat-bottomed 96-well plates, and incubated at $35^{\circ} \mathrm{C}$ under constant agitation for $1.5 \mathrm{~h}$. Then, supernatants were gently aspirated to remove any remaining non-adhering cells, and $100 \mu \mathrm{L}$ of fresh medium with or without antifungal agents were added to the wells.

The choice of antifungal agent concentrations to be tested against biofilms was based on MIC values obtained for the treatment of planktonic cells. The following concentrations of antifungal agents were tested: 0.5 , 2,8 and $32 \mu \mathrm{g} / \mathrm{mL}$ of AMB; 2, 8, 32 and $64 \mu \mathrm{g} / \mathrm{mL}$ of FLC; and 31.25, 125, 500 and $1,000 \mu \mathrm{g} / \mathrm{mL}$ of fraction F2 or subfraction F2.4. After the addition of antifungal agents, plates were incubated for 24 or $48 \mathrm{~h}$ at $35^{\circ} \mathrm{C}$ under constant agitation.

To evaluate the susceptibility of mature biofilms to antifungal agents, biofilm formation was allowed to proceed for $24 \mathrm{~h}$ at $35^{\circ} \mathrm{C}$. After mature biofilms were formed, the supernatant was removed, $100 \mu \mathrm{L}$ of fresh medium with or without antifungal agents (in the same concentrations described above) were added to the wells, and the plates were incubated for a further 24 - or 48 -h period, at $35^{\circ} \mathrm{C}$ and under constant agitation.

After biofilm formation in the presence of the antifungals or mature biofilm treatment, the supernatant containing the dispersive cells was collected in eppendorf tubes for future analysis and the biofilm was quantified using two different approaches.

Metabolic activities of sessile and dispersion cells from C. albicans biofilms after antifungal treatments (during biofilm formation or on mature biofilm) were measured using a tetrazolium reduction (XTT) assay [25]; and the biofilm total biomass was quantified by crystal violetbased assays [27].

\section{Scanning electron microscopy (SEM)}

C. albicans ATCC 10231 biofilms were formed over 5-mm sections of central venous catheters (CVCs), as previously described [28], in the presence or absence of antifungal agents at concentrations corresponding to $64 \times$ MIC $(32$ $\mu \mathrm{g} / \mathrm{mL}$ AMB, $1,000 \mu \mathrm{g} / \mathrm{mL}$ fraction F2 or subfraction F2.4). Antifungal treatments were also performed on mature biofilms. Catheters containing biofilms were fixed in $2.5 \%$ glutaraldehyde and $4 \%$ formaldehyde, in $0.1 \mathrm{M}$ cacodylate buffer, for $1 \mathrm{~h}$ at room temperature, and post-fixed in $1 \%$ osmium tetroxide and $1.25 \%$ potassium ferrocyanide (in $0.1 \mathrm{M}$ cacodylate buffer) for $30 \mathrm{~min}$. The samples were dehydrated in ethanol increasing concentrations, critical-point-dried in $\mathrm{CO}_{2}$, coated with gold and observed in a FEI-Quanta 250 scanning electron microscope (FEI, Japan).

\section{Statistical analyses}

Statistical analyses were performed on the PRISM 5.0 software (Graphpad, USA), using the Dunnett's test (one-way analysis of variance). Statistical significance was accepted when $\mathrm{p}<0.05$.

\section{Results and discussion}

The main objective of the present work was to evaluate the effect of fractions F2 and subfraction F2.4 (proanthocyanidins polimeric tannins) from $S$. adstringens against C. albicans biofilm formation and mature biofilms (previously formed for $24 \mathrm{~h}$ before drug treatment). S. adstringens was selected for this work because it is commonly used in the treatment of vaginal infections in Brazil, where C. albicans is the main fungal pathogenic species [2].

Given that biofilm cells are notoriously more resistant to antifungal therapy than planktonic (suspension) cells $[19,20,29]$, we evaluated the inhibitory activity of $S$. adstringens fractions on C. albicans ATCC 10231 biofilms using concentrations of these fractions higher than the MIC values determined on planktonic cells. Kuhn and coworkers [30] reported that anti-biofilm activity is achieved at considerably higher drug concentrations (8-32 and 321,024 fold, for AMB and FLC, respectively) than those used for planktonic cell growth inhibition. Considering that fraction F2 and subfraction F2.4 behaved similarly to FLC and AMB when tested against planktonic cells, we defined that our analysis should cover concentrations up to 64 fold the MIC value for planktonic cells, which represented the higher limit of the therapeutic range of these fractions.

C. albicans ATCC 10231 planktonic cells were susceptible to treatment with fraction F2 and subfraction F2.4 (MIC values of $15.6 \mu \mathrm{g} / \mathrm{mL}$ for both). The MIC values obtained for C. albicans ATCC 10231 were slightly higher than those previously observed by our group for other isolates of Candida spp. (MIC values between 0.97 and 7.80 $\mu \mathrm{g} / \mathrm{mL})$ [7]. For comparison, MIC values for FLC $(1 \mu \mathrm{g} /$ $\mathrm{mL})$ and AMB $(0.5 \mu \mathrm{g} / \mathrm{mL})$ were also determined in parallel. MFC values revealed that only AMB had a fungicidal effect, whereas FLC, F2 and F2.4 had fungistatic effect against planktonic cells (MFC values of $1 \mu \mathrm{g} / \mathrm{mL}$ for AMB, $64 \mu \mathrm{g} / \mathrm{mL}$ for FLC, and $250 \mu \mathrm{g} / \mathrm{mL}$ for both F2 and F2.4).

S. adstringens fractions presented an inhibitory activity against C. albicans ATCC 10231 biofilms formation comparable to the standard antifungals (AMB and FLC) (Figure 1). F2 and F2.4 were also active against mature biofilm sessile cells (Figure 2), and against dispersed 


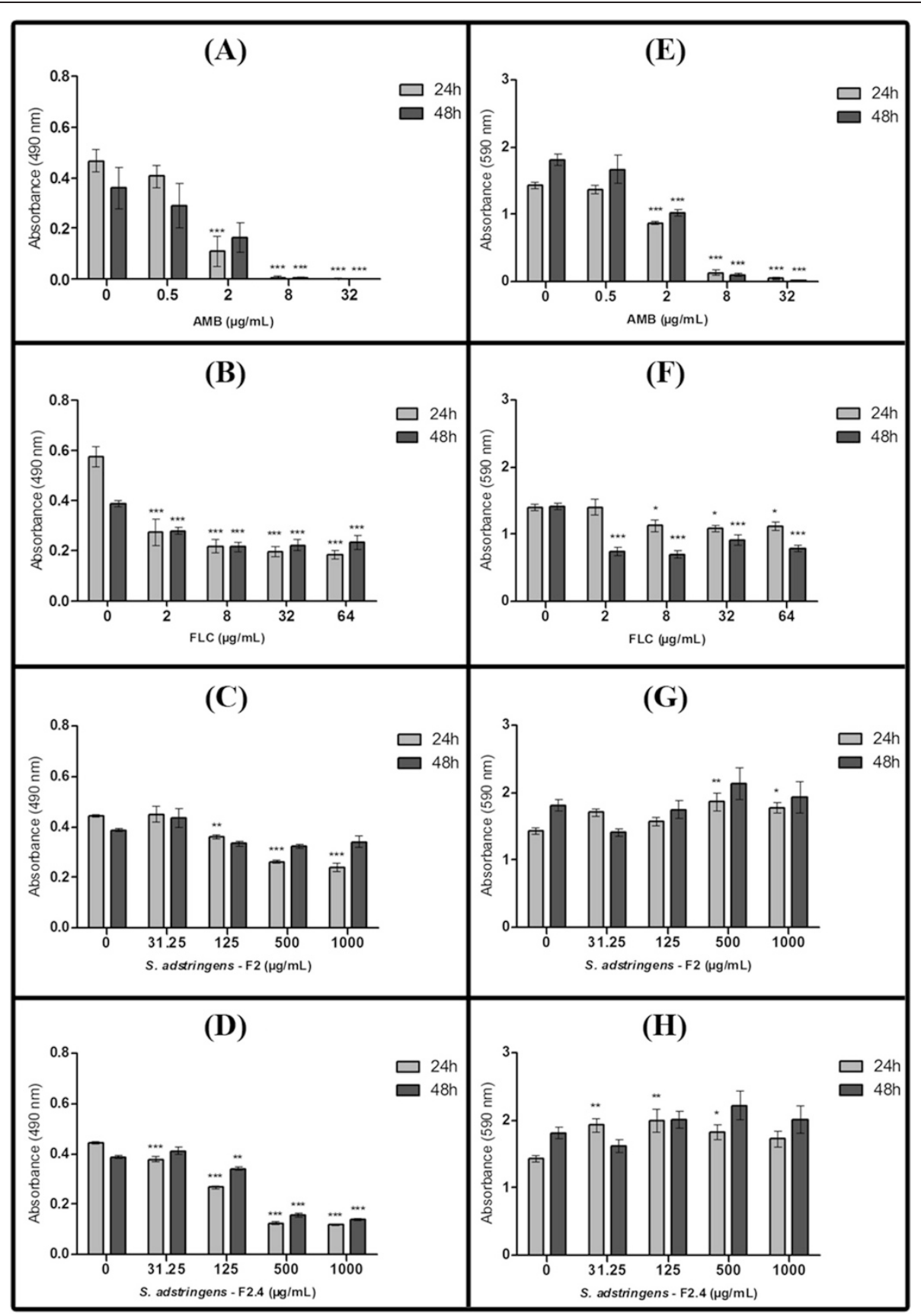

Figure 1 Effect of fraction F2 and of subfraction F2.4 from Stryphnodendron adstringens on the biofilm formation of Candida albicans ATCC 10231. The metabolic activity of biofilm sessile cells was quantified using an XTT assay (A-D) and total biofilm biomass was quantified using a cristal violet-based assay (E-H), after growth in the presence of amphotericin $\mathbf{B}(\mathbf{A}$ and $\mathbf{E})$, fluconazole (B and $\mathbf{F})$, F2 (C and $\mathbf{G})$ or F2.4 ( $\mathbf{D}$ and $\mathbf{H}$ ), for 24 or $48 \mathrm{~h}$, at $35^{\circ} \mathrm{C}$, and under agitation. The error bar represents the standard error of the mean. ${ }^{*} p<0.05 ;{ }^{* *} p<0.01 ;{ }^{* * *} p<0.0001$ (compared to untreated biofilms, using the Dunnett's test).

cells from biofilm (Figure 3). On the other hand, the standard antifungal FLC, which prevents biofilm formation, does not affect the metabolic activity of sessile cells from mature biofilm, neither the spread of infection by biofilm dispersion cells (Figures 1,2 and 3).
All antifungal tested here caused a dose-dependent decrease in the metabolic activity of biofilm sessile cells with a highest antifungal activity observed after $24 \mathrm{~h}$ of treatment, during biofilm formation (Figure 1A-D). AMB was the most active antifungal and concentrations as low 


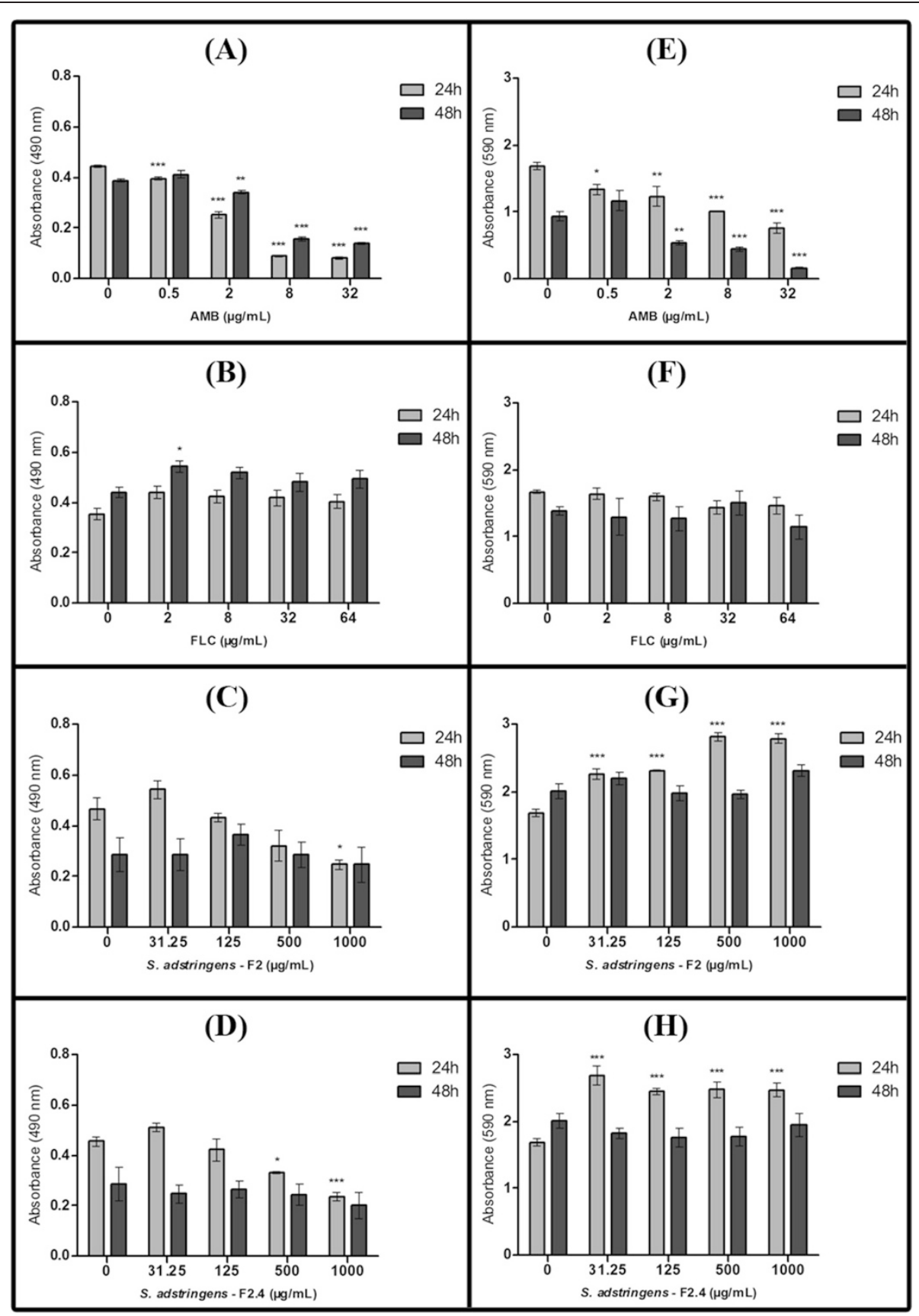

Figure 2 Effect of fraction F2 and of subfraction F2.4 from Stryphnodendron adstringens on mature biofilms of Candida albicans ATCC 10231. The metabolic activity of biofilm sessile cells was quantified using an XTT assay (A-D), and the total biofilm biomass was quantified using a cristal violet-based assay $(\mathbf{E}-\mathbf{H})$. Biofilms formed for $24 \mathrm{~h}$ at $35^{\circ} \mathrm{C}$ were treated for 24 or $48 \mathrm{~h}$, at $35^{\circ} \mathrm{C}$ (and under agitation) with amphotericin $\mathrm{B}$ ( $\mathbf{A}$ and $\mathbf{E})$, fluconazole (B and $\mathbf{F})$, F2 (C and $\mathbf{G})$ or F2.4 (D and $\mathbf{H})$. The error bar represents the standard error of the mean. ${ }^{*} p<0.05 ;{ }^{* *} p<0.01$; ${ }^{* * *} p<0.0001$ (compared to untreated biofilms, using the Dunnett's test).

as $2 \mu \mathrm{g} / \mathrm{mL}(4 \times \mathrm{MIC})$ of this drug were able to inhibit up to $78 \%$ and $57 \%$ of biofilm sessile cells metabolism at $24 \mathrm{~h}$ and $48 \mathrm{~h}$, respectively. Total inhibition of biofilm sessile cells metabolism (98\% at $24 \mathrm{~h}$ of incubation) was observed at concentration $\geq 8 \mu \mathrm{g} / \mathrm{mL}(\geq 16 \times \mathrm{MIC})$ of AMB (Figure 1A). FLC inhibited $52 \%$ of biofilm sessile cells metabolism after $24 \mathrm{~h}$ or $48 \mathrm{~h}$, when $2 \mu \mathrm{g} / \mathrm{mL}(2 \times$ MIC) were used, and only $41 \%$ of biofilm sessile cells 


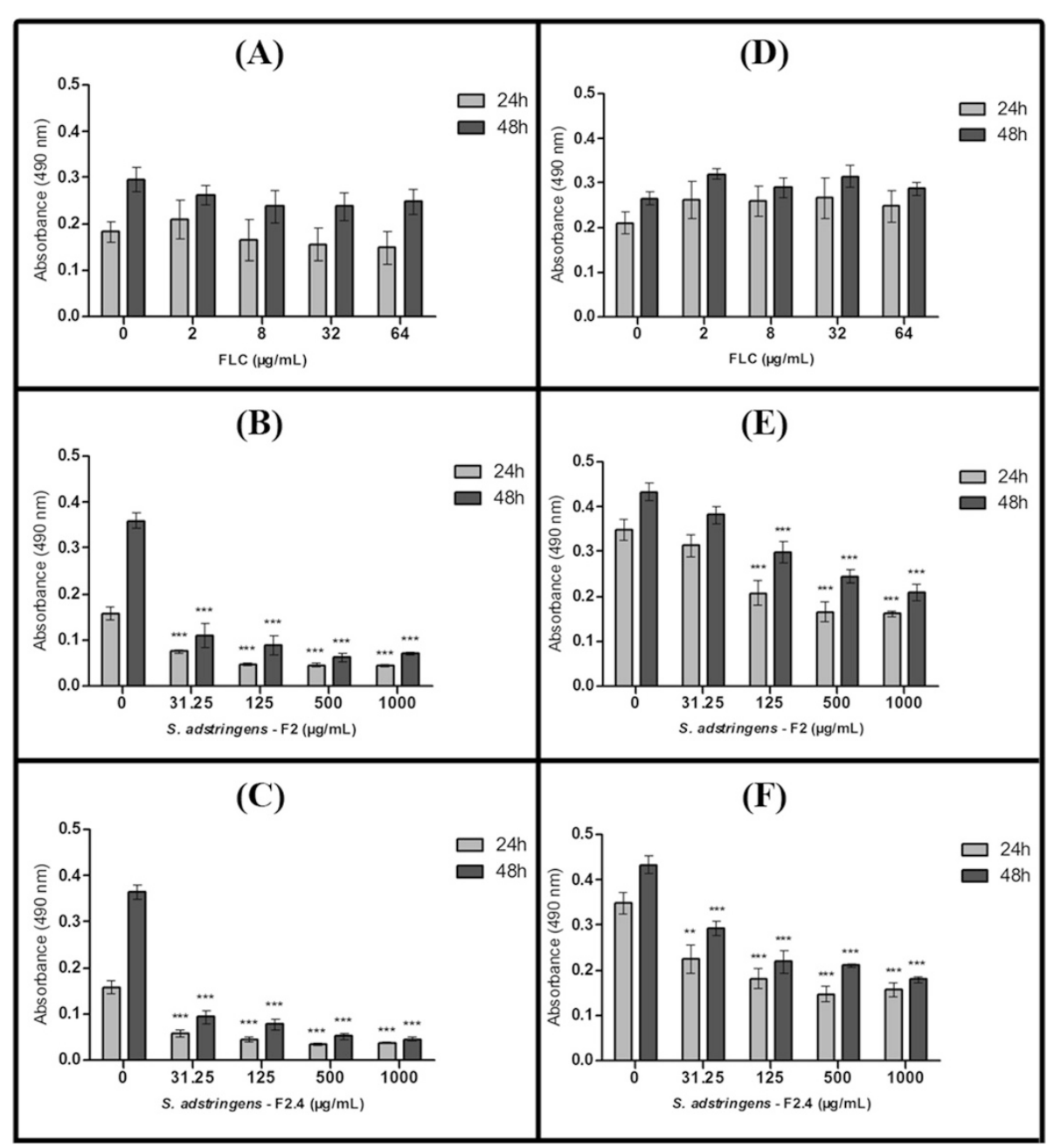

Figure 3 Effect of fraction F2 and of subfraction F2.4 from Stryphnodendron adstringens on dispersion cells from biofilms of Candida albicans ATCC 10231. The metabolic activity of dispersion cells was estimated using an XTT assay, using dispersion cells collected from biofilms under formation (A - C) or mature (formed for $24 \mathrm{~h}$ at $35^{\circ} \mathrm{C}$, prior to the start of treatment) (D - F). Biofilms were treated for 24 or $48 \mathrm{~h}$ at $35^{\circ} \mathrm{C}$ with fluconazole (A and D), F2 (B and E) or F2.4 (C and F). Dispersion cells from biofilms treated with amphotericin B were not analyzed, since these were found in insufficient numbers to allow accurate quantification. The error bar represents the standard error of the mean. ${ }^{*} \mathrm{p}<0.01$; ${ }^{* * *} p<0.0001$ (compared to untreated biofilms, using the Dunnett's test).

metabolism after $48 \mathrm{~h}$ of incubation, using the maximum concentration of $64 \mu \mathrm{g} / \mathrm{mL}(64 \times$ MIC) during biofilm formation (Figure 1B).

Among the $S$. adstringens fractions tested here, subfraction F2.4 significantly inhibited biofilm sessile cells metabolism at concentrations $\geq 31.25 \mu \mathrm{g} / \mathrm{mL}(2 \times \mathrm{MIC})$ $(\mathrm{p}<0.05)$ (Figure 1D). However, the greatest effect was observed at concentration $\geq 500 \mu \mathrm{g} / \mathrm{mL}(\geq 32 \times \mathrm{MIC})$, when $72 \%$ inhibition of biofilm sessile cells metabolism was observed after $24 \mathrm{~h}$ of incubation, and $60 \%$ inhibition after $48 \mathrm{~h}$ (Figure 1D). The effect of fraction F2 on the metabolism of biofilm sessile cells was less pronounced after $24 \mathrm{~h}$ of biofilm formation (up to $47 \%$ inhibition at $1,000 \mu \mathrm{g} / \mathrm{mL}$ ), and no significant inhibitory effect was observed after $48 \mathrm{~h}$ of incubation (Figure 1C).
Further, metabolic activity quantification revealed that subfraction F2.4 was more effective at inhibiting biofilm formation than fraction F2 (Figures $1 C$ and D).

The total biofilm biomass after treatment with antifungal during biofilm formation, including both viable and non-viable cells was quantified using a CV staining assay (Figures 1E-H). Despite the reduction in biofilm metabolic activity after treatment with F2 and F2.4, there was no significant change in the total biofilm biomass even after $48 \mathrm{~h}$ of incubation with the highest concentrations of these fractions. However, AMB treatment resulted in a dose-dependent reduction of the total biofilm biomass, with complete inhibition of biofilm formation at concentrations $\geq 8 \mu \mathrm{g} / \mathrm{mL}(\geq 16 \times \mathrm{MIC})(\mathrm{p}<0.001)$, comparing to the untreated group (Figure 1E). Also, a reduction in 
the biofilm biomass of $32-50 \%$ was observed with FLC treatment at concentrations $\geq 2 \mu \mathrm{g} / \mathrm{mL}(\geq 2 \times \mathrm{MIC})$ after $48 \mathrm{~h}$ of incubation ( $<0.001$; Figure 1F).

Mature biofilms of C. albicans ATCC 10231 were less susceptible to $\mathrm{AMB}$ than biofilms under development (Figure 2A). Treatment with $2 \mu \mathrm{g} / \mathrm{mL}(4 \times$ MIC) AMB resulted in an inhibition of $44 \%$ and $13 \%$ of biofilm sessile cells metabolic activity, after $24 \mathrm{~h}$ and $48 \mathrm{~h}$ of incubation, respectively (Figure $2 \mathrm{~A})$. When $32 \mu \mathrm{g} / \mathrm{mL}(64 \times \mathrm{MIC})$ of AMB was used, reductions of $82 \%$ and $65 \%$ in sessile cells metabolism were achieved, after $24 \mathrm{~h}$ and $48 \mathrm{~h}$ of treatment, respectively (Figure 2A). Although FLC treatment resulted in higher inhibition of biofilm formation compared to fractions from S. adstringens (Figure 1B-D), FLC had no significant effect on mature biofilms at any of the concentrations tested (Figure 2B), while treatment of mature biofilms for $24 \mathrm{~h}$ with $1,000 \mu \mathrm{g} / \mathrm{mL}(64 \times \mathrm{MIC})$ of fraction F2 or of subfraction F2.4 reduced by $47 \%$ and $51 \%$ the metabolic activity of mature biofilm sessile cells, respectively (Figure $2 \mathrm{C}$ and $\mathrm{D}$ ).

Treatment of mature biofilms with AMB resulted in a dose-dependent reduction in biofilm biomass (Figure 2E), matching the corresponding reduction in biofilm metabolic activity after treatment (Figure 2A). AMB induced a prominent reduction of mature biofilm biomass (37$80 \%)$ at concentrations $\geq 2 \mu \mathrm{g} / \mathrm{mL}(\geq 4 \times \mathrm{MIC} ; \mathrm{p}<0.001)$, after $48 \mathrm{~h}$ of incubation, comparing to the untreated group (Figure 2E). The total biomass of mature biofilms was not reduced after treatment with FLC, fraction F2 or subfraction F2.4 at concentrations up to $64 \times$ MIC after both 24 and $48 \mathrm{~h}$ incubation periods (Figure 2F-H), despite the decrease in metabolic activity observed on biofilm cells after treatment with F2 and F2.4 (Figure 2C and D). In addition, the total biomass of mature C. albicans biofilms increased in comparison with the untreated group after $24 \mathrm{~h}$ of incubation with F2 or F2.4 (Figure $2 \mathrm{G}$ and $\mathrm{H}$ ). We hypothesized that this could be happening for two reasons: (i) metabolically inactive cells remain attached to biofilms upon drug treatment, contributing to maintain biofilm biomass; and/or (ii) the extracellular matrix (ECM) of biofilms increases during treatment, as a protective mechanism against proantocyanidin polymeric tannins from S. adstringens.

In C. albicans biofilms, the ECM can prevent antifungal agent penetration into the innermost biofilm layers [20], acting as a physical barrier to protect cells embedded in the biofilm community from the access of antimicrobial agents, thus increasing biofilm drug resistance. The efficiency of the ECM as an 'obstacle' to drug penetration seems to depend on the amount and nature of the matrix, as well as on the physicochemical properties of the antifungal drug [20]. Further, the ECM quantification assays performed on treated biofilms should clarify the importance (if any) of increased ECM production in biofilm biomass maintenance during treatment with FLC, F2 or F2.4.

Fractions F2 and subfraction F2.4 from S. adstringens were more effective at inhibiting biofilm formation, but these fractions were also active against mature biofilms. Still, both fraction F2 and subfraction F2.4 were more effective against mature biofilms than FLC, which did not affect pre-formed biofilms (Figure 2A-D). Biofilms are considerably more resistant to antifungal drugs than planktonic cells, and this statement is particularly true for azoles (such as FLC) [19,29]. Indeed, despite the poor effectiveness of FLC against biofilms, this drug is the first option for the treatment of superficial and mucosal Candida infections [29]. Although fractions F2 and F2.4 were overall less effective than AMB against $C$. albicans, previous works showed that extracts from $S$. adstringens are less toxic to red blood cells and to epithelial cells than polyene agents (such as AMB) [13]. Still, doses used in this work were safely within the therapeutic window reported for fraction F2 in rodent models $[17,18]$. Absence of F2 genotoxicity to mice at concentrations as high as 2,250 $\mathrm{mg} / \mathrm{kg}$ were also reported [17]. Lethal dose of $3,015 \mathrm{mg} / \mathrm{kg}$ [18] and chronic treatment for 90 days with $100-200 \mathrm{mg} /$ $\mathrm{kg}$ did not affect blood biochemical parameters or tissue morphology as demonstrated by Costa et al. [18].

During biofilm development, cells that become detached from biofilms are known as 'dispersion cells' [31]. These cells are particularly important for disease progression, because they may colonize other sites in the host, expanding the infection or, in the worst case scenario, starting a disseminated infection [31]. This cells display distinct virulence properties when compared to their planktonic counterparts, including enhanced adherence, filamentation, biofilm formation, and increased pathogenicity in a murine model of hematogenously disseminated candidiasis [31]. The dispersion cells from biofilms were also analysed in this work (except for those from AMB treated samples, where biofilm growth was too insipid to yield a sufficient number of dispersion cells for analysis). Dispersion cells from biofilm formation or from mature biofilms displayed a dose-dependent reduction in metabolic activity after treatment with $S$. adstringens fractions, and this effect was more pronounced for the subfraction F2.4 than for fraction F2 (Figure 3B-F). Dispersion cells from biofilms formed in the presence of $S$. adstringens fractions at concentrations $\geq 31.25 \mu \mathrm{g} / \mathrm{mL}(\geq 2 \times$ MIC $)$ had significantly reduced metabolic activity in comparison to those released from untreated biofilms after $24 \mathrm{~h}$ or $48 \mathrm{~h}$ of treatment (fraction F2, 49-83\% of inhibition; subfraction F2.4, 61-89\% of inhibition) (Figure 3B and C). Both fractions yielded metabolic activity inhibition in dispersion cells above $50 \%$, as early as $24 \mathrm{~h}$ after the start of treatment on mature biofilm at concentrations $\geq 500 \mu \mathrm{g} / \mathrm{mL}$ $(\geq 32 \times \mathrm{MIC})(\mathrm{p}<0.001)$ (Figure 3E and F). Moreover, F2 
and F2.4 were significantly more effective at reducing the metabolic activity of dispersion cells from biofilms than treatment with FLC, where dispersion cell metabolic activity was similar to that observed in the untreated group (Figure 3A and D). These exciting results suggest that treatment with proantocyanidins polymer-rich fractions from $S$. adstringens stem bark might be able to prevent the dissemination of $C$. albicans infections, due to its effect on metabolic activity of dispersion cells.

Morphological effects on C. albicans biofilms treated with AMB, F2 and F2.4 were evaluated by scanning electron microscopy (SEM) images (Figures 4 and 5). Untreated C. albicans biofilms showed a dense network of filamentous form fungi formed for $24 \mathrm{~h}$ (biofilm formation assay) (Figure $4 \mathrm{~A}-\mathrm{C}$ ) and $48 \mathrm{~h}$ (mature biofilm assay) (Figure 5A-C). Treatment with AMB inhibited the fungal filamentation process with most biofilm cells retaining the yeast form (Figure 4D-F; Figure 5D-F). Treatments with fraction F2 or subfraction F2.4 (Figure 4G-L; Figure 5G-L) induced alterations mainly in blastoconidia, with the formation of 'dumbbell-shaped' cells (white arrows in Figures 4I, L and 5I, L), suggestive of an effect on the budding process, as previously described for C. albicans planktonic cells treated with subfraction F2.4 [7]. Treatment with F2.4 also induced the arising of blastoconidia clusters in biofilms (Figures $4 \mathrm{~K}, \mathrm{~L}$ and $5 \mathrm{~K}, \mathrm{~L}$ ), similarly
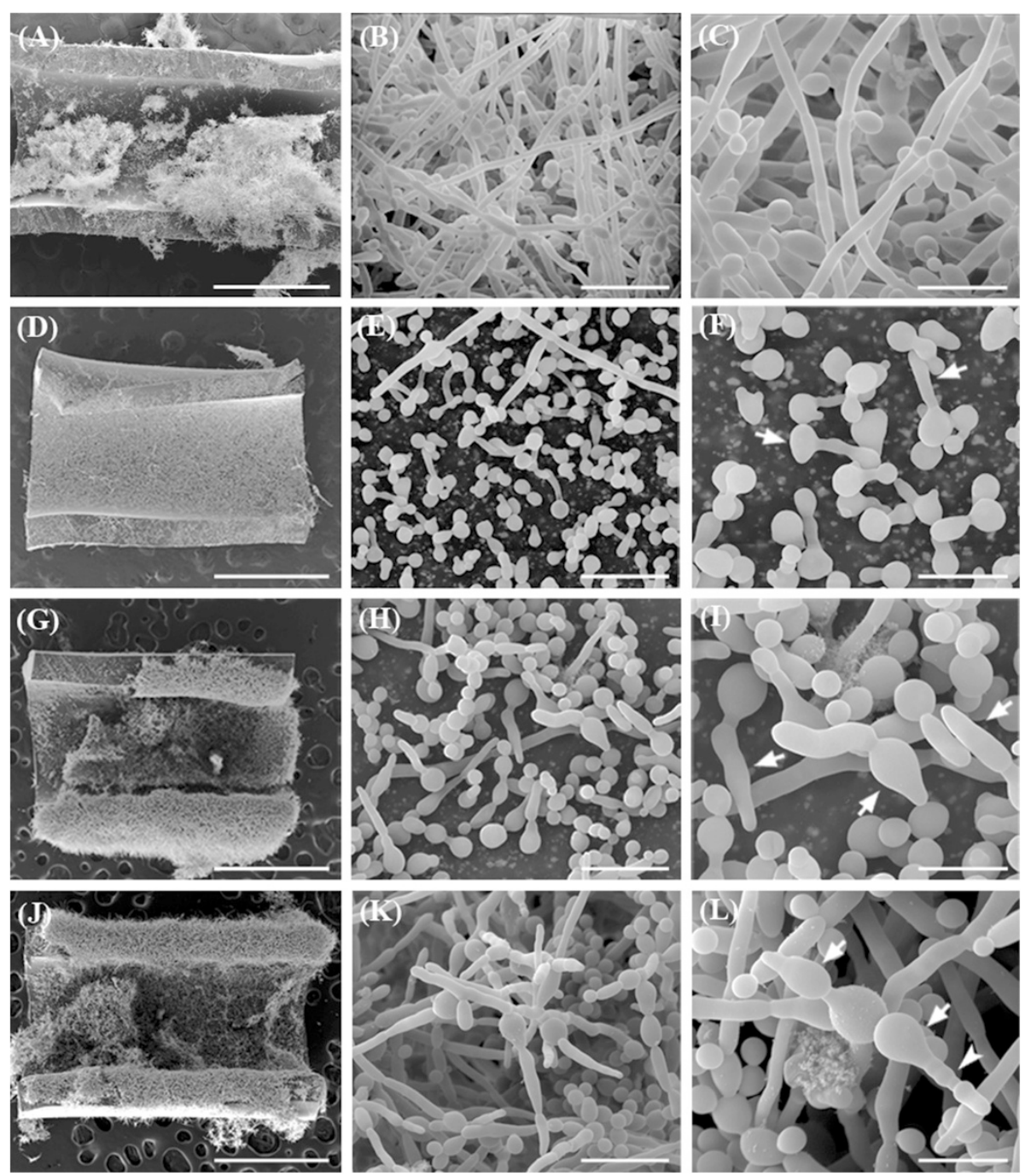

Figure 4 Scanning electron microscopy of Candida albicans ATCC 10231 biofilms formed in the presence of fraction F2 or subfraction F2.4 from Stryphnodendron adstringens. Biofilms were treated with antifungal agents concentrations 64 fold higher than the minimum inhibitory concentration (MIC) values determined for the treatment of planktonic cells for $24-\mathrm{h}$ incubations at $35^{\circ} \mathrm{C}$. Compared to untreated controls (A-C), biofilms formed in the presence of $32 \mu \mathrm{g} / \mathrm{mL}$ amphotericin B (D-F) displayed a reduction in fungal biomass, with filamentation inhibition and the presence of irregular buds (arrows in F). Treatment with $1,000 \mu \mathrm{g} / \mathrm{mL}$ of fraction F2 (G-I) or subfraction F2.4 (J-L) led to the formation of biofilms with blastoconidia cells of altered shape, including 'dumbell' cells (I and $L$, arrows) and those with elongated bud necks (L, arrowhead). Scale bars: $1 \mathrm{~mm}$ (A, D, G and J), $20 \mu \mathrm{m}$ (B, E, H and $\mathbf{K})$ and $10 \mu \mathrm{m}(\mathbf{C}, \mathbf{F}, \mathbf{I}$ and $\mathbf{L})$. 

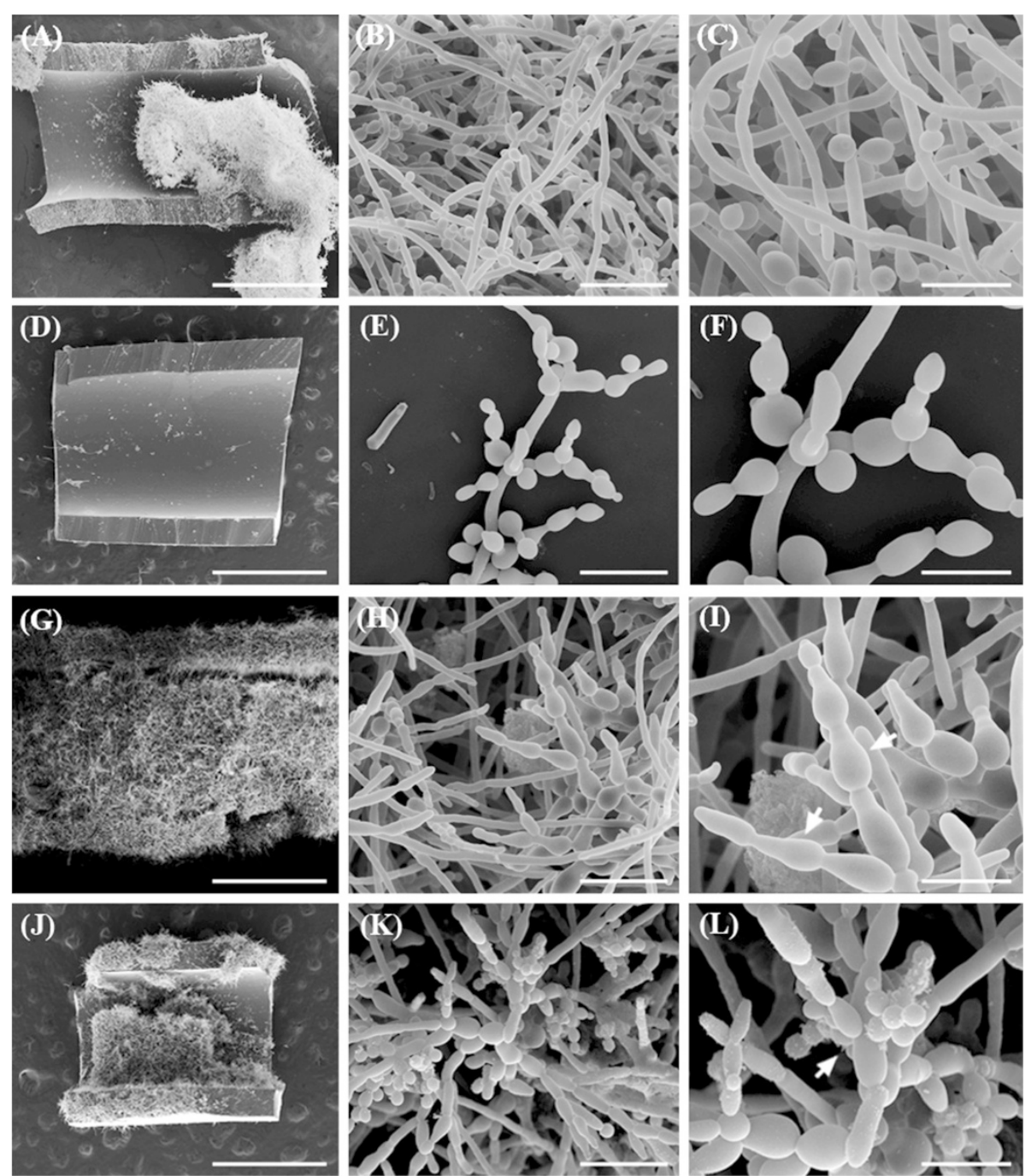

Figure 5 Scanning electron microscopy of mature biofilms from Candida albicans ATCC 10231 treated with fraction F2 or subfraction F2.4 from Stryphnodendron adstringens. Mature biofilms formed during 24-h incubations at $35^{\circ} \mathrm{C}$ were treated for an additional $24 \mathrm{~h}$ in the same conditions, with antifungal agent concentrations 64 fold higher than the minimum inhibitory concentration (MIC) values determined for the treatment of planktonic cells. Compared to untreated controls (A-C), mature biofilms treated with $32 \mu \mathrm{g} / \mathrm{mL}$ amphotericin B (D-F) induced a reduction in the fungal biomass. Treatment with $1,000 \mu \mathrm{g} / \mathrm{mL}$ of fraction F2 (G-I) or subfraction F2.4 (J-L) induced the formation of elongated blastoconidia cells (arrows in I and L), and treatment with subfraction F2.4 also induced the formation of blastoconidia clusters (arrow in L). Scale bars: $1 \mathrm{~mm}$ (A, D, G and $\mathbf{J}), 20 \mu \mathrm{m}(\mathbf{B}, \mathbf{E}, \mathbf{H}$ and $\mathbf{K}), 10 \mu \mathrm{m}(\mathbf{C}, \mathbf{F}, \mathbf{I}$ and $\mathbf{L})$

to previous results of our group for C. albicans planktonic cells treated with subfraction F2.4 [7].

Proanthocyanidins are oligomeric flavonoids composed by derivatives of catechin and epicatechin and their gallic acid esters. More complex structures composed of the same polymeric building blocks form the group of condensed tannins. The present work is the first report of the activity of proanthocyanidins polymeric tannins against fungal biofilms. However, other reports have demonstrated the antifungal the activity of flavonoid molecules against planktonic cells of yeast $[32,33]$ and filamentous fungi [34]. Recently, Shahzad et al. [35] described the inhibitory activity of some monomeric polyphenols, including flavonoids, on planktonic cells of C. albicans and on C. albicans biofilms (at concentrations $78.12->1,000 \mu \mathrm{g} / \mathrm{mL}$ and $39.06->5,000 \mu \mathrm{g} / \mathrm{mL}$, respectively).

Subfraction F2.4 was obtained from the aqueous fraction F2 by chromatography using a Sephadex LH-20 column [7], and was identified as a polymeric tannin of molecular weight of 2,114 Da, composed of six monomers of proanthocyanidins (prodelphinidin and prorobinetinidin) and gallic acid residues [5-7]. The degree of polymerization of polyphenols appears to be related to antifungal activity, possibly because the reactivity of tannins with macromolecules (including both proteins and 
carbohydrates) increases progressively with the degree of polymerization $[36,37]$.

The antifungal properties of $S$. adstringens against planktonic cells of Candida spp. and $C$. neoformans have been attributed to this polymeric tannin $[7,16]$. Our data demonstrate that proantocyanidin polymeric tannin-rich fractions from S. adstringens stem bark (fraction F2 and subfraction F2.4) are also active against biofilms of C. albicans, likely due to the presence of this proantocyanidins polymeric tannin in these fractions. At safe doses, both F2 and F2.4 inhibited biofilm formation and reduced the metabolic activity of mature biofilm cells. Interestingly, these fractions also reduced the metabolic activity of dispersion cells, indicating that they could inhibit infection dissemination mediated, at least in part, by this cell population. Thus, these polymeric tannins can affect a particularly drug-resistant stage of biofilm development.

\section{Conclusion}

This is the first report of the anti-biofilm activity of proanthocyanidins polymeric tannins from $S$. adstringens stem bark (fraction F2 and subfraction F2.4) and being an important finding, since the development of new and cheaper compounds for the treatment of biofilm-related fungal infections is sorely needed. Therefore, fraction F2 and subfraction F2.4 from S. adstringens shows great potential in the search for new therapy against Candida infections involving biofilm formation.

\section{Abbreviations \\ ECM: Extracellular matrix; SEM: Scanning electron microscopy; MIC: Minimal inhibitory concentration; MFC: Minimal fungicidal concentration; AMB: Amphotericin B; FLC: Fluconazole; ${ }^{13} \mathrm{C}$ NMR: Carbon nuclear magnetic resonance.. \\ Competing interests \\ The authors report no conflicts of interests and are responsible for the contents and writing of this paper.}

\section{Authors' contributions}

RLFL carried out all the experiments and drafted the manuscript. TVMV, SR and $\mathrm{KI}$ designed and coordinated the study. JCPM and CVN provided the fractions used in this work helped to draft the manuscript. TVMV, SR and KI wrote the manuscript. All authors read, contributed and approved the final manuscript.

\section{Acknowledgements}

The authors thank Beatriz Bastos Fonseca for helping with SEM sample preparation. This work was supported by Fundação de Amparo à Pesquisa do Estado de São Paulo (FAPESP - Processo no. 2013/11232-0), Fundação Carlos Chagas Filho de Amparo à Pesquisa do Estado do Rio de Janeiro (FAPERJ), Coordenação de Aperfeiçoamento de Pessoal de Nível Superior (CAPES), and Conselho Nacional de Desenvolvimento e Pesquisa (CNPq). RLFL and TVMV are fellows of the CNPq.

\section{Author details}

'Laboratório de Biologia Celular de Fungos, Instituto de Biofísica Carlos Chagas Filho, Universidade Federal do Rio de Janeiro, Rio de Janeiro, RJ, Brazil. 'Laboratório de Biologia Farmacêutica, Palafito, Departamento de Farmácia Universidade Estadual de Maringá, PR, Brazil. '²aboratório de Inovação Tecnológica no Desenvolvimento de Fármacos e Cosméticos, Departamento de Ciências Básicas da Saúde, Universidade Estadual de
Maringá, PR, Brazil. ${ }^{4}$ Laboratório de Quimioterapia Antifúngica, Departamento de Microbiologia, Instituto de Ciências Biomédicas, Universidade de São Paulo, Av. Prof. Lineu Prestes 1374, 05508-900 SP, Brazil.

Received: 19 August 2014 Accepted: 28 February 2015

Published online: 19 March 2015

\section{References}

1. Kourkoumpetis T, Manolakaki D, Velmahos G, Chang Y, Alam HB, De Moya MM, et al. Candida infection and colonization among non-trauma emergency surgery patients. Virulence. 2001;1:359-66.

2. Sobel JD. Vulvovaginal candidosis. Lancet. 2007;369:1961-71.

3. Nucci M, Queiroz-Telles F, Tobón AM, Restrepo A, Colombo AL. Epidemiology of Opportunistic Fungal Infections in Latin America. Clin Infect Dis. 2010;51:561-70.

4. Agência Nacional de Vigilância Sanitária: Farmacopéia Brasileira. 5th ed, Brasília, Brazil, 2010, pp. 808

5. Mello JCP, Petereit F, Nahrstedt A. Flavan-3-ols and prodelphinidins from Stryphnodendron adstringens. Phytochemistry. 1996:41:807-13.

6. Mello JCP, Petereit F, Nahrstedt A. Prorobinetinidins from Stryphnodendron adstringens. Phytochemistry. 1996;42:857-62.

7. Ishida K, Mello JCP, Cortez DA, Dias Filho BP, Ueda-Nakamura T, Nakamura CV. Influence of tannins from Stryphnodendron adstringens on growth and virulence factors of Candida albicans. J Antimicrob Chemother. 2006:58:942-9.

8. Panizza S, Rocha AB, Gecchi R, Souza e Silva RAP. Stryphnodendron barbadetiman (Vellozo) Martius: teor em tanino na casca e sua propriedade cicatrizante. Rev Bras Ciências Farm. 1988;10:101-6.

9. Lima JCS, Martins DTO, De Souza PT. Experimental evaluation of stem bark of Stryphnodendron adstringens (Mart.) Coville for anti-inflammatory activity. Phyther Res. 1998;12:218-20.

10. Audi EA, Toledo DP, Peres PG, Kimura E, Pereira WK, Mello JC, et al. Gastric antiulcerogenic effects of Stryphnodendron adstringens in rats. Phyther Res Res. 1999:13:264-6.

11. Herzog-Soares JD, Alves RK, Isac E, Bezerra JCB, Gomes MH, Santos SC, et al. Atividade tripanocida in vivo de Stryphnodendron adstringens (barbatimão verdadeiro) e Caryocar brasiliensis (pequi). Rev Bras Farmacogn. 2002;12:1-2.

12. Holetz FB, Ueda-Nakamura T, Dias Filho BP, Mello JCP, Morgado-Díaz JA, Toledo CE, et al. Biological effects of extracts obtained from Stryphnodendron adstringens on Herpetomonas samuelpessoai. Mem Inst Oswaldo Cruz. 2005;100:397-401.

13. Luize PS, Tiuman TS, Morello LG, Maza PK, Ueda-Nakamura T, Dias Filho BP, et al. Effects of medicinal extracts on growth of Leishmania (L.) amazonensis and Trypanosoma cruzi. Brazilian J Pharm Sci. 2005;41:1-10.

14. Felipe AMM, Rincão VP, Benati FJ, Linhares RE, Galina KJ, Toledo CE, et al. Antiviral effect of Guazuma ulmifolia and Stryphnodendron adstringens on poliovirus and bovine herpesvirus. Biol Pharm Bull. 2006:29:1092-5.

15. Audi EA, Toledo CEM, Santos FS, Bellanda PR, Alves-do-Prado W, UedaNakamura T, et al. Biological activity and quality control of extract and stem bark from Stryphnodendron adstringens. Acta Farm Bonaer. 2004;23:328-33.

16. Ishida K, Rozental S, Mello JCP, Nakamura CV. Activity of tannins from Stryphnodendron adstringens on Cryptococcus neoformans: effects on growth, capsule size and pigmentation. Ann Clin Microbiol Antimicrob. 2009:8:29-38.

17. Costa MA, Ishida K, Kaplum V, Koslyk ED, Mello JCP, Ueda-Nakamura T, et al. Safety evaluation of proanthocyanidin polymer-rich fraction obtained from stem bark of Stryphnodendron adstringens (BARBATIMÃO) for use as a pharmacological agent. Regul Toxicol Pharmacol. 2010;58:330-5.

18. Costa MA, Mello JCP, Kaneshima EN, Ueda-Nakamura T, Dias Filho BP, Audi EA, et al. Acute and chronic toxicity of an aqueous fraction of the stem bark of Stryphnodendron adstringens (Barbatimão) in rodents. Evidence-Based Complement Altern Med. 2013; 1-9

19. Mukherjee PK, Chandra J. Candida biofilm resistance. Drug Resist Updat. 2004;7:301-9.

20. Seneviratne CJ, Jin L, Samaranayake LP. Biofilm lifestyle of Candida: a mini review. Oral Dis. 2008;14:582-90.

21. Pappas PG, Kauffman CA, Andes D, Benjamin Jr DK, Calandra TF, Edwards Jr $J E$, et al. Clinical Practice Guidelines for the Management of Candidiasis: 2009 Update by the Infectious Diseases Society of America. Clin Infect Dis. 2009;48:503-35.

22. Costa MA. Investigação da atividade toxicológica e farmacológica da fração rica em polímeros de proantocianidina, obtida das cascas de 
Stryphnodendron adstringens (Mart.) Coville (Barbatimão). Maringá: Tese (Doutorado em Ciências Farmacêuticas) Universidade Estadual de Maringá; 2011. p. 149

23. Clinical and Laboratory Standards Institute (CLSI): Reference Method for Broth Dilution Antifungal Susceptibility Testing of Yeasts-Third Edition: Approved Standard M27-A3. CLSI, Wayne, PA, USA, 2008.

24. Pfaller MA, Sheehan DJ, Rex JH. Determination of Fungicidal Activities against Yeasts and Molds- Lessons Learned from Bactericidal Testing and the Need for Standardization. Clin Microbiol Rev. 2004;17:268-80.

25. Jin Y, Yip HK, Samaranayake YH, Yau JY, Samaranayake LP. Biofilm-forming ability of Candida albicans is unlikely to contribute to high levels of oral yeast carriage in cases of human immunodeficiency virus infection. J Clin Microbiol. 2003:41:2961-7.

26. Braga PC, Culici M, Alfieri M, Dal Sasso M. Thymol inhibits Candida albicans biofilm formation and mature biofilm. Int J Antimicrob Agents. 2008:31:472-7.

27. Silva S, Henriques M, Martins A, Oliveira R, Williams D, Azeredo J. Biofilms of non- Candida albicans Candida species: quantification, structure and matrix composition. Med Mycol. 2009;47:681-9.

28. Vila TVM, Ishida K, de Souza W, Prousis K, Calogeropoulou T, Rozental S. Effect of alkylphospholipids on Candida albicans biofilm formation and maturation. J Antimicrob Chemother. 2012;68:113-25.

29. Ramage G, Bachmann S, Patterson TF, Wickes BL, López-Ribot JL. Investigation of multidrug efflux pumps in relation to fluconazole resistance in Candida albicans biofilms. J Antimicrob Chemother. 2002;49:973-80.

30. Kuhn DM, George T, Chandra J, Mukherjee PK, Ghannoum MA. Antifungal Susceptibility of Candida Biofilms: Unique Efficacy of Amphotericin B Lipid Formulations and Echinocandins. Antimicrob Agents Chemother. 2002:46(6):1773-80.

31. Uppuluri P, Chaturvedi AK, Srinivasan A, Banerjee M, Ramasubramaniam AK, Köhler JR, et al. Dispersion as an Important Step in the Candida albicans Biofilm Developmental Cycle. PLoS Pathog. 2010;6:e1000828.

32. Sitheeque MA, Panagoda GJ, Yau J, Amarakoon AMT, Udagama URN, Samaranayake LP. Antifungal Activity of Black Tea Polyphenols (Catechins and Theaflavins) against Candida Species. Chemother. 2009;55:189-96.

33. Silva CR, Andrade Neto JB, Campos RS, Figueiredo NS, Sampaio LS, Magalhães HIF, et al. Synergistic Effect of the Flavonoid Catechin, Quercetin, or Epigallocatechin Gallate with Fluconazole Induces Apoptosis in Candida tropicalis Resistant to Fluconazole. Antimicrob Agents Chemother. 2014;58(3):1468-78.

34. Park BJ, Taguchi H, Kamei K, Matsuzawa T, Hyon SH, Park JC. In Vitro Antifungal Activity of Epigallocatechin 3-O-Gallate against Clinical Isolates of Dermatophytes. Yonsei Med J. 2011;52(3):535-8.

35. Shahzad M, Sherry L, Rajendran R, Edwards CA, Combet E, Ramage G. Utilising polyphenols for the clinical management of Candida albicans biofilms. Int J Antimicrob Agents. 2014;44:269-73.

36. Santos SC, Costa WF, Ribeiro JP, Guimarães DO, Ferri PH, Ferreira HD, et al. Tannin composition of barbatimão species. Fitoterapia. 2002;73:292-9.

37. Field JA, Lettinga G. Toxicity of tannic compounds to microorganisms. In: Hemingway RW, Laks PE, editors. Plant polyphenols. New York: Plenum Press; 1992. p. 673-89.

\section{Submit your next manuscript to BioMed Central and take full advantage of:}

- Convenient online submission

- Thorough peer review

- No space constraints or color figure charges

- Immediate publication on acceptance

- Inclusion in PubMed, CAS, Scopus and Google Scholar

- Research which is freely available for redistribution 